\title{
Integration of Lean Six sigma in Reducing Waste in the Cutting Disk Process with the DMAIC, VSM, and VALSAT Method Approach in Manufacturing Companies
}

\author{
Muhammad Kholil ${ }^{1}$, Jakfat Haekal ${ }^{2}$, Adizty Suparno ${ }^{3}$, Muhammad Rizki ${ }^{4} \&$ Tri Widodo \\ ${ }^{1-4}$ Industrial Engineering Department, Faculty of Engineering, University of Mercu Buana \\ ${ }^{5}$ Industrial Engineering Department, Faculty of Engineering \\ University of Muhammadiyah Tanggerang, Indonesia
}

\begin{abstract}
The Indonesian Manufacturing Company is a manufacturing company that produces two-wheeled automotive spare parts. One of the products currently being supplied to several two-wheeled customers is the disc brake, rear sprocket, and drive sprocket. The opportunity to increase production output adjusted to high customer demand can be done by reducing waste activities. Therefore, an approach with a lean six sigma approach is needed using the integration method of DMAIC (Define, Measure, Analyze, Improve, and Control), VSM (Value Stream Mapping), and VALSAT. This research aims to reduce production waste and reduce cycle time, which affects increasing production output to balance according to customer needs. Waste identification is explained in the Define stage at DMAIC using a big mapping image in Value Stream Mapping. Then a more in-depth analysis is carried out using the VALSAT tools at the Analyze stage, which is supported by WRM and WAQ questionnaire data. The Analyze stage was then carried out by analyzing using the FMEA method. Control is carried out by standardization and outreach to employees. This study aims to identify and reduce waste that occurs in the production area, especially line-cutting disks. Based on the VALSAT analysis, it was found that the four biggest wastes were motion, inventory, overproduction, waiting, transportation, and the process, which had five wasteful activities. First, the chuck design used is still separate; it should be improved by combining the soft jaw and chuck into one component. Second, the accumulation of material after M.H. Drilling is improved by combining inner and outer cutting processes into one process. Third, the counterbore process still uses the manual depth setting method using a micrometer which can be reduced by the process between M.H. Drilling, Counter Bore, and Mounting Hole Chamfering are made into one process, using Brother NC machines using hydraulic clamps. Fourth, the location between the inner and outer cutting machines with the mounting hole drilling is still too far away for improvement, namely from the line cutting disk layout a relayout was made to U LINE. Fifth, human errors often occur during the chamfering process by adding a stopper to the machine to prevent human errors.
\end{abstract}

Keywords: Lean Manufacturing, DMAIC, VSM, VALSAT.

\section{INTRODUCTION}

The development of the manufacturing and service industry sector is growing increasingly fierce, causing open competition on a national and international scale. Every company will always make every effort to improve the quality and quantity of its products so that it continues to gain the trust of its consumers. Therefore, there needs to be a factor that can help maintain the product on the market in this case. To survive and compete in the market, a company always tries in various ways to stay ahead of competitors by creating high productivity, efficiency, and high-quality products, to be able to compete in the market (Muhammad Kholil, Rudina Mulya, 2014)

Productivity can be interpreted as comparing the value generated from an activity (output) to the total value of the input used (input) in carrying out these activities. At the company level, management is often used to analyze, measure, and improve the efficiency of the production process and measure how optimally the company uses its resources to produce the products it wants. Therefore, every company needs to measure its productivity level to improve company performance to win the global 
competition. Productivity measurements that are carried out periodically and continuously can provide information about the company's growth pattern that can then be forecast for the future. L. Greenberg defines productivity as Comparing the total expenditure at a particular time to the totality of inputs during that period (Yosan et al., 2014).

The Indonesian Manufacturing Company is an automotive industry company that is engaged in manufacturing automotive components. Its main products are Disk Brakes, Rear Sprockets, and Drive Sprockets for various two-wheeled motor vehicles. Its main customers are Suzuki, Honda, Kawasaki, Yamaha, and Harley. Customers Manufacturing Indonesia is a large company that produces two-wheeled motorized vehicles and is required to meet customer needs and satisfaction.

Based on this, the Indonesian Manufacturing Company constantly improves every element of its company, including production activities starting from the production work system, raw material requirements, labor requirements, etc. Of the three products produced, Disk Brake is the component that is produced the most. However, in the production process, various problems impact output, one of which is the ineffective use of existing machines and human resources, seen from the increase in customer orders to Indonesian Manufacturing Companies. The following is an example of a product image produced by an Indonesian Manufacturing Company.

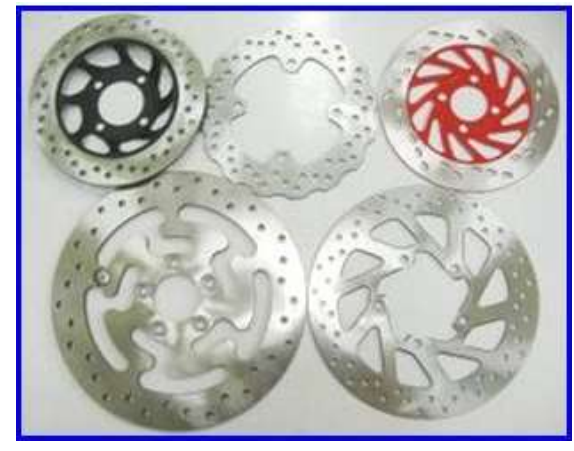

Figure 1 Disk Brake Products

By paying attention to the current condition of the company, are there any factors that indicate the ups and downs of production and affect the course of the production process so that productivity needs to be measured

The Indonesian Manufacturing Company has many disk brake products, some of which are BK-U, 45KA-M1, 45KB-M2, 410061, 2DP-00, 41H-14, 42K-M1, 4KA-M2, 1RC-00.

The problem with the Indonesian Manufacturing Company itself is that during the development period, it is the cycle time process that is not stable between one process and another and cannot meet the high customer needs for mass production. This occurs because of an imbalance in the production line at the cutting disk line due to the unequal distribution of workloads in each workstation. This has an impact on work productivity performance. The following is the cutting disk cycle time data in the production process section.

Table 1 Cutting Disk Cycle Time, 2020

\begin{tabular}{|c|l|c|c|}
\hline No. & \multicolumn{1}{|c|}{ Process } & $\begin{array}{c}\text { Man } \\
\text { Power }\end{array}$ & $\begin{array}{c}\text { Cycle Time } \\
\text { Proses/pcs } \\
\text { (second) }\end{array}$ \\
\hline 1 & Inner Diameter Cutting & 1 & 283 \\
\hline 2 & Outer Diameter Cutting & 1 & 297 \\
\hline 3 & Mounting Hole Drilling & 1 & 179 \\
\hline 4 & Mounting Hole Chamfering & 1 & 59 \\
\hline 5 & Counter Bore & 1 & 111 \\
\hline 6 & Counter Bore Chamfering & 1 & 58 \\
\hline
\end{tabular}


In the current condition in the cutting disk production line, as shown in the table above, the cycle time in the Inner diameter cutting process is $283 \mathrm{sec}$, and the Outer diameter is cutting with a cycle time of $297 \mathrm{sec}$. While the cutting process is still in one production line, namely the cutting section, when combined, the total cycle time generated from the Inner diameter of the cutting and the cutting section's outer diameter is $580 \mathrm{sec}$, when converted into is 10 minutes. The bottleneck that occurs results in an accumulation of Work In Process after the Inner diameter cutting process leads to the Outer diameter cutting process, which results in reduced and weak production line productivity in the cutting disk process. Time is long enough for a production process and material setup. Meanwhile, mounting hole drilling, mounting hole chamfering, counterbore, and counterbore chamfering are still separate processes so that waiting times and movements take a long time.

The problem faced by the Indonesian Manufacturing Company is the division of the workload to balance the production line on the cutting disk line. The purpose of balancing the cutting disk production line is to identify the production process by identifying waste, reducing disruptions, increasing production capacity and work efficiency at each work station, and carrying out a series of continuous improvement activities

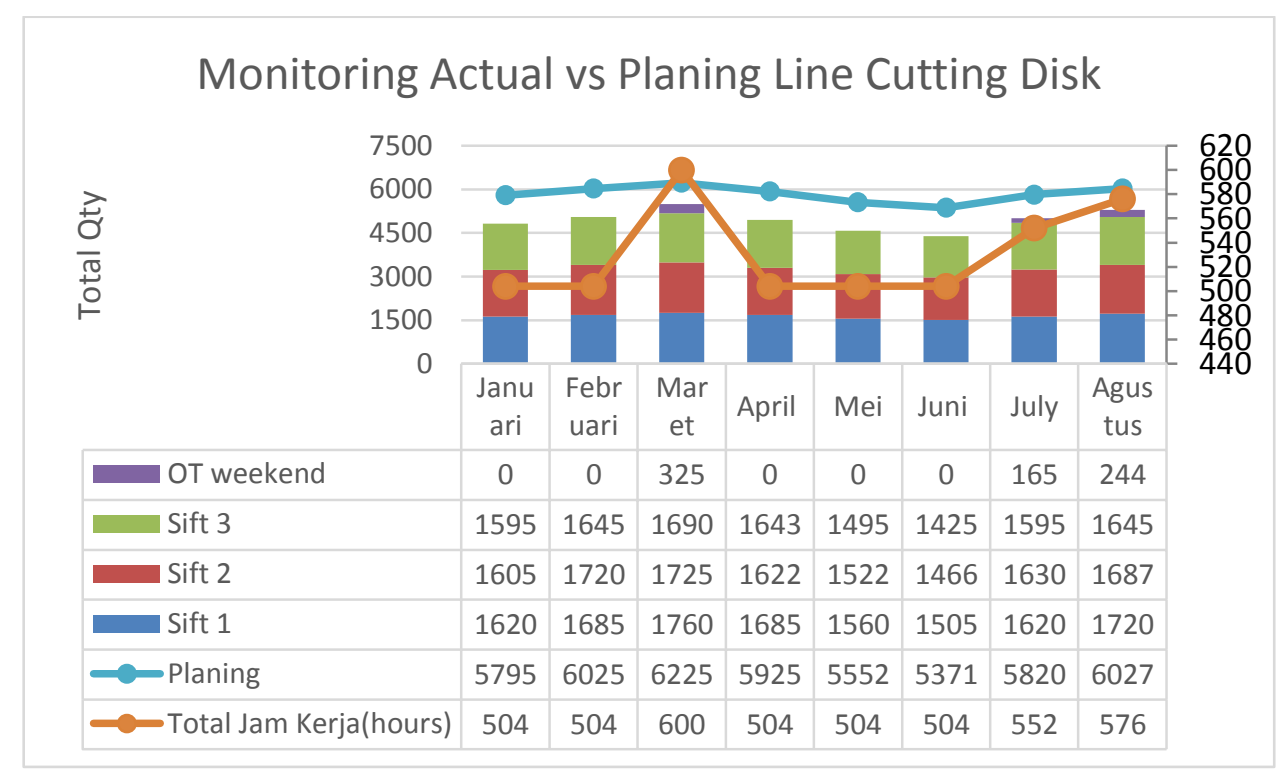

Figure 2 Line Cutting Disc Comparison Chart, 2020

From the data above, it can be concluded that the cutting process is not achieved every month, which causes the remaining production to be carried out in the sub count. This decreases the cutting disk process's productivity and increases the cost of processing in the sub count.

Because of this, the authors intend to make improvements to improve work methods in the cutting disk process. One of the methods used in the optimization of a production line is the lean method. Lean manufacturing is a systematic approach to identify and eliminate waste through a series of improvement activities. (Shodiq \& Khannan, 2015). Several methods that will be used to optimize the balance of the disk brake production path are DMAIC (Define, Measure, Analyze, Improve, and Control), VSM (Visual Stream Mapping), and VALSAT (Value Stream Analysis Tools).

In other references, six Sigma is a tool or tool used to improve processes through customer focus, continuous improvement, and the involvement of people both inside and outside the organization. Six Sigma is a continuous improvement process that prioritizes the DMAIC stage (defining, measuring, analyzing, improving, controlling). DMAIC is carried out systematically based on science and facts towards the six sigma target, namely 3.4 defects per million opportunity (DPMO) and, of course, increasing the company's profitability (Vinilon et al., 2015).

The purpose of VSM is to identify the production process so that materials and information can run without interruption, increase productivity and competitiveness, and assist in implementing the system (Sasongko et al., 2019). Therefore, VSM helps in finding waste in the production process. VALSAD is a tool that assists in a more comprehensive analysis of the results of the VSM 
analysis. The primary function of VALSAT is as a method that helps find the causes of waste in the production process (Fernando, 2014).

This method is expected to provide a solution as an alternative to improve the production line's balance performance so that the cutting production process in making disc brakes becomes more efficient, effective, and productive. This method will become a priority reference for improvements that must be carried out.

\section{LITERATURE SURVEY}

\subsection{Lean Manufacturing}

Lean manufacturing is a concept that can design a production process to be better, faster, and cheaper with minimal space, small inventory, small labor hours, and avoid waste (Womack in Firmansyah et al., 2019). Waste or waste in lean manufacturing is divided into 7 (seven wastes), namely overproduction, wait for time waste, transportation, overprocessing, inventory, motion, and defects / rejects.

Lean is a management system that is entirely focused on efficiency, is a long-term growth philosophy through efforts to increase customer, community, and economic value to reduce costs, accelerate service time, and improve quality through the total elimination of waste (Boss \& Frank in Hospital et al. ., 2016). Lean is not about "downsizing" or reducing the number of employees. Lean is about having the right resources in the right place to do the job that the customer needs, at the best quality and at the right time.

According to (V. Gaspersz in Rini Fitriyani et al., 2019), there are five basic principles of lean, namely:

1. Identify the product's value (goods and / services) based on the customer's perspective. The customer wants a product (goods/service) of superior quality at competitive prices with on-time service.

2. Identify the value stream process mapping (mapping processes to the value stream) for each product (goods/services).

3. Eliminate unnecessary waste from all activities along the value stream.

4. Organizing so that materials, information, and products flow smoothly and efficiently throughout the value stream process using a pull system.

5. Seek continuously various techniques and tools of improvement to achieve excellence and continuous improvement.

According to (Hines \& Taylor in Rini Fitriyani et al. 2019), the principle of lean thinking is to find ways for the value creation process in the best possible order, arrange these activities without interruption, and explain more and more effectively. Lean thinking provides fewer people, equipment, time and space, but gets closer to consumers. According to (Hines \& Taylor in Rini Fitriyani et al. 2019), there are several stages in lean thinking, namely:

1. Understand waste

2. Set goals

3. Understanding the Big Picture

4. Detailed Mapping

5. Involving suppliers and customers, and

6. Review the plans made

According to (Kilpatrick in Rini Fitriyani et al., 2019), the implementation of lean will be able to provide many benefits for the company, as follows:

1. Can reduce the cycle time (lead time)

2. Can increase productivity

3. Can reduce work in process (WIP)

4. Can improve product quality

5. Can make fair use of space by reducing distance. 
International Journal of Engineering Research and Advanced Technology, Vol. 7, No.9, September -2021

Lean Manufacturing Method Approach

In this research, the lean approach is carried out using three methods or tools, namely DMAIC (Define, Measure, Analyze, Improvement and Control), VSM (Visual Stream Mapping), and VALSAT (Value Stream Analysis Tools).

2.2 DMAIC (Define, Measure, Analyze, Improvement and Control)

DMAIC is a methodology used in Six Sigma to solve problems that arise. This method is done repeatedly so that the improvement process occurs continuously.

DMAIC is used to improve existing business processes. This method continues to improve all lines of business processes that are being run to compete and dominate the existing market. This methodology aims for continuous improvement of the process to achieve standards and customer desires and satisfaction.

\section{RESEARCH METHODOLOGY}

The research methodology is a research stage that must be determined before carrying out the problem-solving process. Research can be carried out in a more directed and controlled manner to make it easier to analyze existing problems.

\subsection{Types of research}

Based on the formulation of the problem posed in the previous chapter, this research is classified as quantitative research because, in its implementation, it includes data in the form of numbers or numerals. Following its form, quantitative data can be processed or analyzed using mathematical calculation techniques.

\subsection{Types of Data and Information}

The data collected is data related to the problem-solving process discussed in both primary and secondary data. Primary data is used for processing, while secondary data is used to support primary data.

For this research, the authors collected the following information data:

There are two types of data based on the source of collection and can be classified as follows:

1. Primary Data

Primary data is data that is obtained directly (first hand). Primary data is obtained using measuring instruments or direct data collection on the subject (person) as a source of information. Primary data is also known as original data or new data that is up to date. To get primary data, researchers must do it directly.

Primary data in this study are:

a. number of workstations and operators.

b. Operation work.

c. Current production layout.

d. Current operating cycle time.

2. Secondary data

Secondary data is obtained from data that has been researched or collected by other parties, which has something to do with the required data. This study's secondary data are company profile, organizational structure, employment, product type, total production capacity, manpower, and efficiency obtained from research reports.

The data used in this study are based on the type, namely:

a. Qualitative data, namely data that is not in the form of numbers, which in this study were obtained from the job descriptions of operators and direct interviews related to the work they were doing.

b. Quantitative data, namely data in the form of computable numbers, which in this study were obtained from measurements of operator working time in one shift. 


\subsection{Method of collecting data}

Data collection is needed to obtain information relating to the object to be studied.

a. Interview

Namely, collecting data and information by asking questions directly to obtain the required data to leaders and operators, and production staff who know the problems to be discussed.

b. Library Research

In preparing this final project, literature research is also carried out, namely by reading and studying the theory contained in books, literature, lecture notes, and journals related to the main problem of this research.

c. Direct Observation

Namely, the method used by direct observation of the object under study to obtain the required information and accurate data. In this case, it is done observing the workings of the cutting process and observing the causes of waste (waste).

\subsection{Data Processing and Analysis Methods}

This research uses qualitative and quantitative data types obtained directly from the company concerned. In this study, data collection is by conducting direct interviews with supervisors or leaders or operators in the disc brake production process in the cutting process, as well as staff related to the production department and PPIC and making direct observations. The analysis was carried out with a lean manufacturing approach using the DMAIC (Define, Measure, Analyze, Improve, and Control) method, VSM (Value Stream Mapping), and VALSAT (Value Stream Analysis Tools).

\subsubsection{Problem analysis}

The analysis section will determine whether the analysis results from data processing can help reduce problems that occur in Indonesian Manufacturing Companies. The analysis that was carried out was as follows:

a. Amount of production currently running in the cutting production line at the manufacture of disc brakes at the Indonesian Manufacturing Company.

b. Production time in the cutting process.

c. The total working time required for the cutting process.

\subsubsection{Lean Six Sigma DMAIC, VSM, and VALSAT integration}

The following are the steps involved in identifying waste for optimization of the line cutting disk:

a. Define, Measure, Analysis, Improve and Control (DMAIC)

DMAIC is a structured problem-solving method often used for quality and process improvement. DMAIC is an implementation of the Six Sigma philosophy. The DMAIC method consists of five main stages, define, measure, analyze, improve, and Control.

\section{The Define Stage}

This stage is the initial stage in six sigma. At this stage, the targeting and identification of the process and bottleneck process will be carried out.

The define stage to determine the waste carried out in this research is integrated with

- Value Stream Mapping (VSM) method by making Big Future Mapping.

- Determine the Value Added (VA) and Non-Value Added (NVA).

2. Measure stage

Several things are done at this stage, namely:

- Calculating test data uniformity 
International Journal of Engineering Research and Advanced Technology, Vol. 7, No.9, September -2021

The data uniformity test was carried out to ensure that the data under study were uniform and did not vary. The data readiness test was carried out by making a graph of Upper Control Limit (BKA) and Lower Control Limit (BKB).

- Calculating the Data Adequacy Test

After conducting the data uniformity test, the next step is to make a data adequacy test to ensure that the data collected is sufficient objectively.

- Calculating Standard, Normal, and Cycle Times

At this stage, the cycle time is calculated by calculating the time obtained from direct observations listed in the stopwatch. The average time that is done is working time that has taken into account the adjustment factor. Standard time is the standard time used by the operator to produce one unit of production type data.

- Calculating Takt Time

Takt Time is a target time that must be achieved by production to meet customer needs. Takt time is a reference for management to set production targets and take the first steps in reducing waste.

- Calculating Capacity Efficiency

The first step in determining production capacity is determining the process cycle time.

\section{Analyze stage}

This stage is the stage of analyzing, looking for, and finding the root cause of a problem. In this study, the analysis stage was carried out using the VALSAT method. The primary function of VALSAT is as a method that helps find the causes of waste in the production process (Hines \& Rich, 1997). The VALSAT tool is used to deepen waste analysis from previous VSM tools using the Waste Relationship Matrix (WRM) questionnaire and the Waste Assessment Questionnaire (WAQ).

At this stage, FMEA (Failure Mode and Effect Analysis) is used to determine priority improvement plans. FMEA is the systematics of activities that identify and evaluate potential failure rates in a system, product, or process, especially at the product's root functions or process on the factors that affect the product or process.

FMEA is a systematic approach that applies a labeling method to assist engineers' thought processes in identifying potential failure modes and their effects (Amin, Syukron, and Muhammad Kholil., 2013).

FMEA aims to develop, increase, and control the probability values of failure detected from the source (input) and reduce the effects caused by the failure (Hidayat et al., 2006). Each type of failure has 1 (one) RPN (Risk Priority Number), which results from multiplying the ranking of severity, detection, and occurrence. Then the RPN is sorted from largest to smallest so that it can be seen the most critical types of failures that are a priority for corrective action.

4. Improve

The improvement stage is carried out by developing the findings and recommendations from the previous FMEA stage to improve the existing system to get better results than the previous condition.

\section{Control}

The final stage of DMAIC is controlled, which is monitoring all improvement activities and making new standards. This stage is an act of control over the stages that have been previously carried out, so documentation and Control are essential to maintain consistency of improvements made to improve quality.

\section{b. Value Stream Mapping (VSM)}

Value stream mapping is a map that summarizes data, describing the production process starting from the supply of materials, the production process until the product is in the hands of the customer. Therefore, VSM helps in finding waste in the production process. The following is an explanation for making Value Stream Mapping.

\section{Make Current Value Stream Mapping}

The current value stream mapping is needed as the basis for making the proposed state map. 
2. Identification of Waste with VSM.

At this stage, the identification of material flow during the production process, activities along the value stream, the cycle time of the assembling process, and the need for the workforce in each activity, and other process data are carried out.

3. Analysis of the Root Cause of Waste.

This analysis was carried out using a fishbone diagram to determine the leading root causes of waste-proposed improvements with Lean Tools, including using a Pareto diagram or a fishbone chart.

\section{Creating a Future State Map}

The future state map is obtained from the results of reducing the waste in the current state map. However, future state mapping still refers to the initial mapping or current state.

\section{c. Value Stream Analysis Tools (VALSAT)}

This method has seven tools to find the causes of waste: process activity mapping, supply chain response matrix, production variety funnel, quality filter mapping, demand amplification mapping, and decision point analysis. The VALSAT concept is used to select detailed mapping that is considered representative to identify the location of waste in the value stream of the production system in the cutting disk line.

The process of selecting this tool is done by multiplying each waste's average score by the value stream mapping suitability matrix. In this study, the three tools with the most considerable total value according to the VALSAT results will be used as the selected mappings. Of these three tools, a more detailed analysis will be carried out. The following is an explanation of each of the tools VALSAT has

\section{Make Current Value Stream Mapping}

Value stream mapping is a map that describes all the steps in the manufacturing process (including rework) associated with converting customer needs into a product and shows how much value each step adds to the product.

2.Waste Relationship Matrix (WRM)

WRM is a matrix consisting of rows and columns (Rawabdeh, 2005 quoted by Mughni, 2012). Each row shows the effect of a particular waste on the other six wastes. Meanwhile, each column shows the waste, which is influenced by other wastes.

3. Waste Assessment Questionnaire (WAQ)

The Waste Assessment Questionnaire is designed to identify and allocate waste that occurs on the production line. The Waste Assessment Questionnaire is carried out by weighting the WAQ questionnaire using the WAQ algorithm. From the weighting results using WAQ, the percentage of each waste that occurs will be obtained.

4. Analysis of the Root Causes of Waste.

This analysis was carried out using a fishbone diagram to determine the leading root causes of waste-proposed improvements with Lean Tools, including using a Pareto diagram or a fishbone chart.

\section{Future value stream mapping}

After analyzing and providing recommendations for improvement, what is next is done by describing the Future State Map. An expectation or expectation of value stream mapping for future conditions after improvement. In this stage, the current state map will be compared with the future state map regarding the lead time before the repair and repair to determine the changes.

\section{RESULT AND DISCUSSION}

\section{Waste Analysis with Integration of DMAIC, VSM and VALSAT}

The problem that is discussed in this research is the cycle time that is too high in the production line due to waste that does not add value to the product. 


\section{Define}

In the define stage, with the aim of discovering the main waste in line cutting disks, it is integrated with the Value Stream Mapping (VSM) method by describing the big picture / current state mapping. At this stage, potential activities can be identified by identifying Value Added (VA) and Non-Value Added (NVA).

\section{Tabel 1 Tabel NVA dan VA}

\begin{tabular}{|c|c|c|c|}
\hline \multirow{2}{*}{ Process } & \multicolumn{2}{|c|}{ Second } & \multirow{2}{*}{ Grand Total } \\
\cline { 2 - 4 } & NVA & VA & \\
\hline Inner Diameter Cutting & 184 & 99 & 283 \\
\hline Outer Diameter Cutting & 184 & 113 & 297 \\
\hline Mounting Hole Drilling & 105 & 74 & 179 \\
\hline Mounting Hole Chamfering & 46 & 13 & 59 \\
\hline Counter Bore & 48 & 63 & 111 \\
\hline Counter Bore Chamfering & 47 & 11 & 58 \\
\hline
\end{tabular}

Based on the NVA and VA tables above, it can be seen that the NVA value is very high so that further analysis is carried out at the measure and analysis stage with the integration of VALSAT tools to reduce the cycle time process and reduce waste on the cutting disk production line.

\section{Measure}

The calculation phase in this study was carried out to measure the average cycle time in the previous condition so as to know the efficiency of the previous condition. The aim is to identify which part of the work station has an excess workload so that workload balancing can be done at each work station.

Table 2 Line Cutting Disc Cycle Times

\begin{tabular}{|l|r|}
\hline Station & \multicolumn{2}{|c|}{ Second } \\
\hline Inner Cutting & 282 \\
\hline Outer Cutting & 290 \\
\hline M.H. Drilling & 179 \\
\hline M.H. Chamfering & 59 \\
\hline Counter Bore & 110 \\
\hline $\begin{array}{l}\text { Counter Bore } \\
\text { Chamfering }\end{array}$ & 59 \\
\hline
\end{tabular}

Based on the table above, it can be concluded that the highest cycle time is in the outer cutting process so that it is defined as a bottleneck and 
production cycle time. Based on the above cycle times with a production capacity in shifts capable of producing 70 pcs per shift, the current production capacity efficiency is $72 \%$.

In an effort to increase efficiency and production capacity, further analysis stages were carried out with VALSAT tools using a Waste Relationship Matrix (WRM) questionnaire and a Waste Assessment Questionnaire (WAQ).

\section{Analyze}

The Analyze stage is carried out by processing data from the results of distributing questionnaires to several related departments (Production, Quality, PPIC and Warehouse) from the staff level to the leader who plays a direct role in the production process. The following is a chart of questionnaire data processing results.

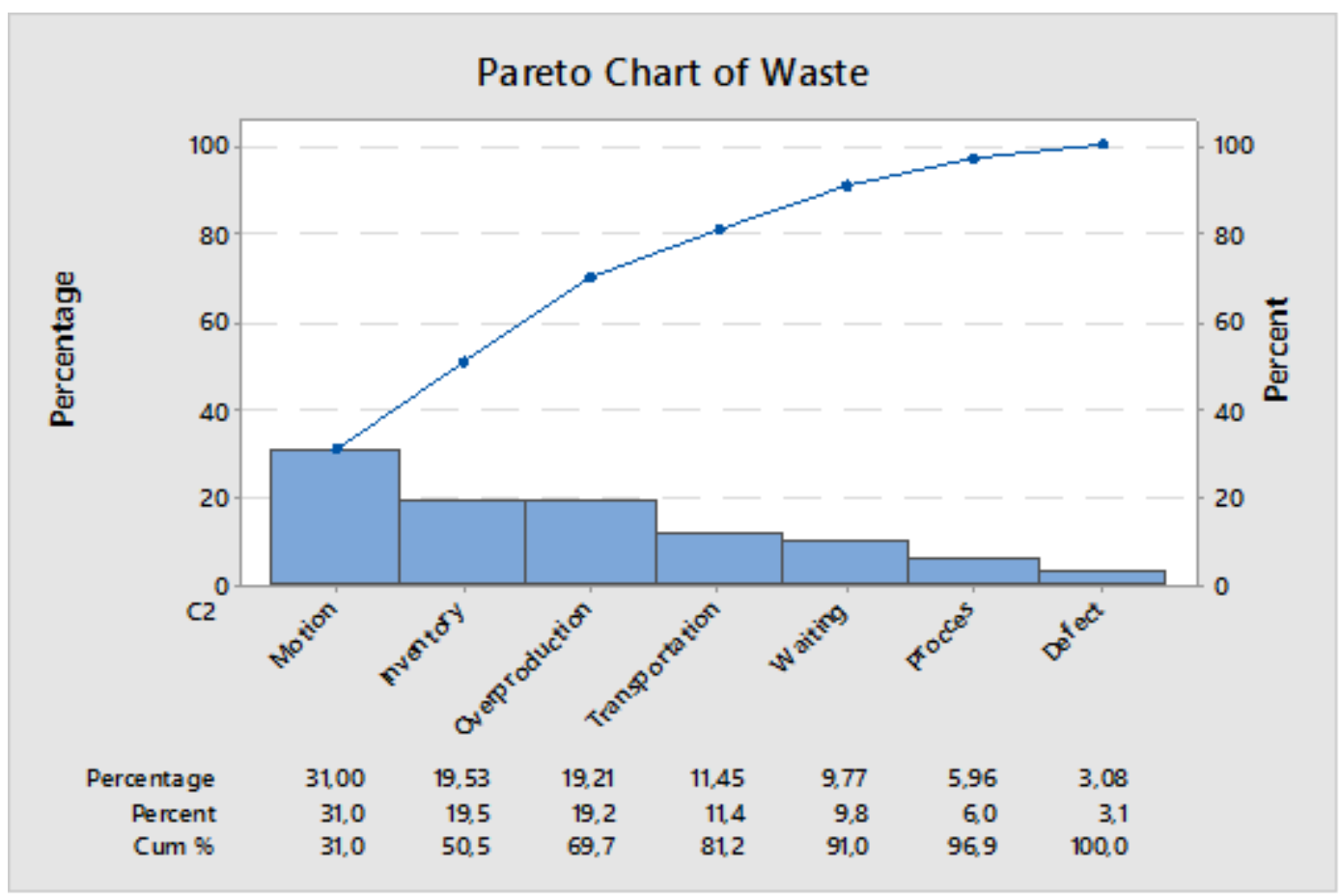

Figure 3 Percentage of Line Cutting Disc Waste Rate

Based on the pareto chart above, it is known that the 6 highest categories of waste have a big influence on the production process in the line cutting disk section so that in the next analysis the 6 largest categories are selected.

The next analysis uses PFMEA tools to find out improvement activities based on the RPN value with the aim of finding out recommendations for improvements based on the greatest priority. Following are the results of the FMEA analysis of the 6 selected waste categories.

Table 3 PFMEA Analysis of Line Cutting Disc Waste Types

\begin{tabular}{|c|c|c|c|c|c|c|c|c|c|}
\hline No & Waste & Failure & $\mathbf{S}$ & $\begin{array}{c}\text { Efek } \\
\text { Kegagalan } \\
\text { Potensial } \\
\end{array}$ & $\mathbf{O}$ & $\begin{array}{c}\text { Penyebab } \\
\text { Potensial }\end{array}$ & D & Rekomendasi & RPN \\
\hline 1 & Motion & $\begin{array}{l}\text { The setting } \\
\text { process for } \\
\text { JIG cutting is } \\
\text { too long }\end{array}$ & 6 & $\begin{array}{l}\text { The chuck and } \\
\text { soft jaw } \\
\text { designs are still } \\
\text { not efficient } \\
\text { enough for the } \\
\text { initial setup }\end{array}$ & 9 & $\begin{array}{l}\text { The movement for } \\
\text { the Chuck and } \\
\text { Soft Jaw set-up is } \\
\text { too long, because } \\
\text { there are two } \\
\text { components for } \\
\text { one set up }\end{array}$ & 7 & $\begin{array}{l}\text { Combining the design } \\
\text { between the chuck and } \\
\text { soft jaw into one } \\
\text { component }\end{array}$ & 378 \\
\hline 2 & Motion & $\begin{array}{c}\text { Waiting time } \\
\text { during the } \\
\text { inner and } \\
\text { outer cutting } \\
\text { process }\end{array}$ & 7 & $\begin{array}{l}\text { In the inner and } \\
\text { outer cutting } \\
\text { process using } 2 \\
\text { machines and } 2 \\
\text { man power }\end{array}$ & 10 & $\begin{array}{l}\text { The chuck design } \\
\text { used is still } \\
\text { separate between } \\
\text { the inner and } \\
\text { outer cutting } \\
\text { processes, so the } \\
\text { process uses } 2 \text { and }\end{array}$ & 6 & $\begin{array}{c}\text { The chuck design } \\
\text { changes are combined } \\
\text { into one inner \& outer } \\
\text { cutting with the stoper } \\
\text { in the Reduction Holes } \\
\text { Part }\end{array}$ & 420 \\
\hline
\end{tabular}


International Journal of Engineering Research and Advanced Technology, Vol. 7, No.9, September -2021

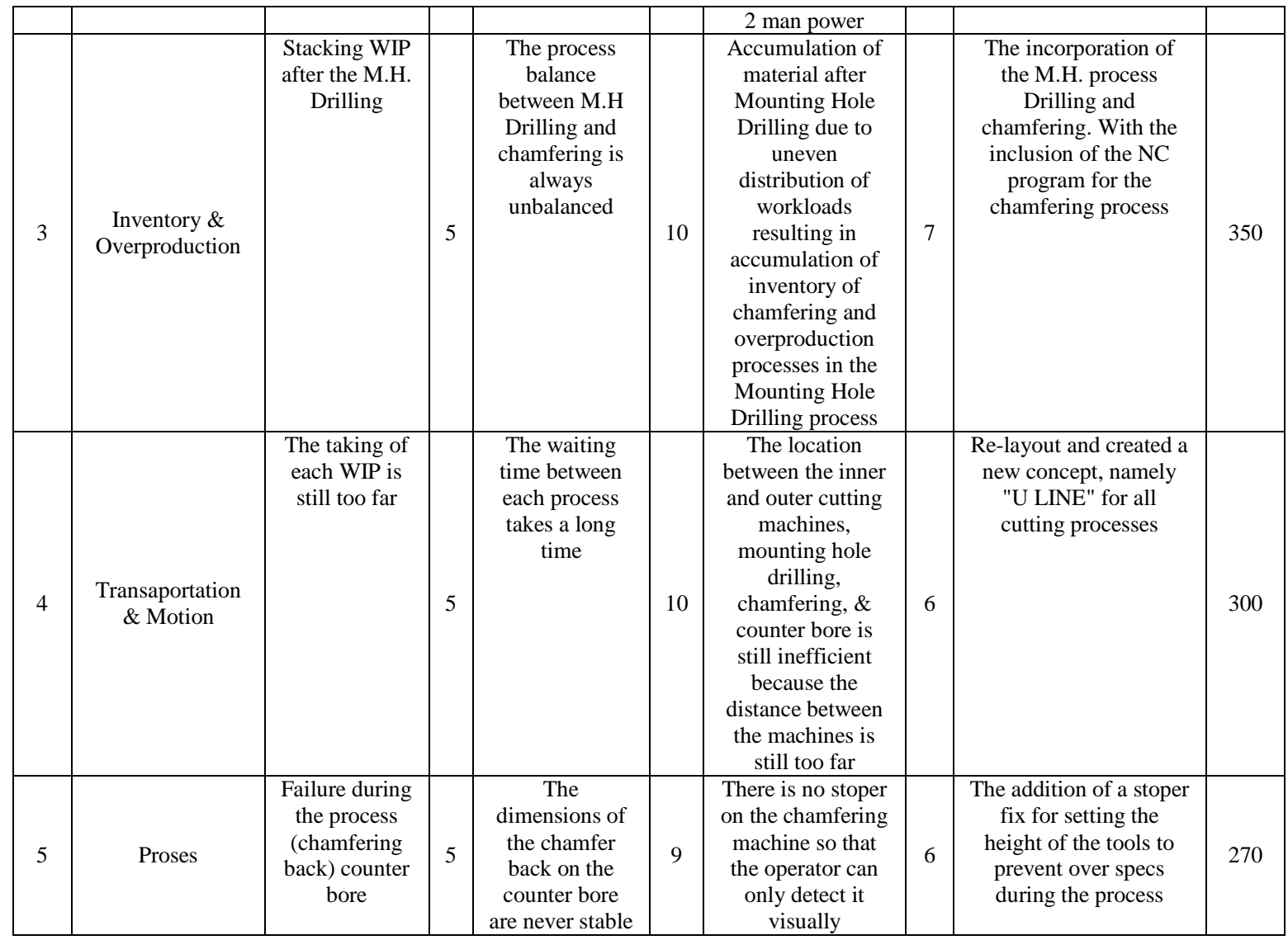

The determination of the severity, occurrence and detection values is based on the author's analysis and brainstoring to several related departments. Based on the results of the RPN in the PFMEA table above, it is known that the highest RPN order is in the inner and outer cutting process which causes the highest waste because it still uses 2 machines and 2 man power, in the chuck and soft jaw set-up process, the accumulation of inventory material after M.H. Drilling due to the uneven distribution of workloads resulting in accumulation of inventory in the chamfering and overproduction processes in the M.H. Drilling, the location between the inner outer, drilling, chamfering, \& counter bore machines is still inefficient because the distance between the machines is still too far, the setting process takes a long time due to manual setting using a micro meter, there is no stoper on the chamfering machine so that the operator can only detect visually.

\section{Improvement}

The improvement activities recommended in the PFMEA tool have a major effect on increasing the capacity efficiency and reducing the production cycle time. The following are improvement activities that were carried out:

\section{a. JIG Setting Process That Is Too Long}

The improvement made is combining soft jaw and chuck into one component. From the results of these improvements, the results show a decrease in the cycle time set up from the previous 30 minutes or 1800 seconds to 10 minutes or 600 seconds. Decrease the cycle time set up by 20 minutes or 1200 seconds.

$\square 10$ minutes: 480 minutes $=0.020$ minutes $(1.25$ seconds $/ 1$ second $)$

b. The Waiting Time for the Inner and Outer Cutting Process is Still Too Long

The improvement made is combining the inner and outer cutting processes into one process. By changing the chuck design into one component. Before repairing the datum for the inner cutting process it was on the outer and vice versa in the outer cutting process the datum was on the inner. After the design is changed to one component, the datum is in the Weight Reduction Hole material. 
After the inner and outer cutting processes are combined, the results of improvements that have been made have been made, namely a reduction in the process cycle time, a reduction in machine usage from 2 machines to 1 machine, and a reduction in man power from 2 man power to 1 man power.

c. WIP Stacking After M.H. Drilling

After improving the process between M.H. Drilling, Counter Bore, and Mounting Hole Chamfering are made into one process. By using the Brother NC machine using a hydraulic clamp with a wind pressure of $4-5$ bar. There is no need for material handling from one process to another. The counter bore process does not use a manual process with a long set up time. Everything has become a component of the process, only setting tools in the NC program to determine the offset height. With a total cycle time of 357 seconds for three processes with one running.

\section{d. Taking of Each WIP Is Still Too Far}

After going through the inner and outer cutting process, the material will be processed by mounting hole drilling. The location between the inner and outer cutting machines with the mounting hole drilling is still too far away, thus creating a long movement time and requiring additional transportation.

To improve the line cutting disk layout, a re-layout was made to U LINE. U-shaped line to make it easier for operators when handling material from each process.

From the results of changes in the line cutting disk layout, it is found that the cycle time is efficient to make it easier for operators during material handling.

\section{e. Failure During Counter Bore Chamfering Process}

The improvements made were the addition of a stoper to the machine to prevent human errors.

From the results of the improvements made in the form of adding bolt stoper to the machine to facilitate the operator during the process so that human error does not occur. And obtained stable results in accordance with the dimensions on the specified process sheet, namely $0.6-0.8 \mathrm{~mm}$.

\section{RESEARCH RESULTS}

a. Value Added and Non Value Added

Reducing waste in making disc brake line cutting disk, here is a comparison of Value Added Time and Non Value Added Time.

Table 4 Comparison of VA \& NVA

\begin{tabular}{|c|c|c|c|c|c|c|c|}
\hline \multirow{2}{*}{$\begin{array}{l}\text { Process } \\
\text { Before } \\
\text { Repair }\end{array}$} & \multicolumn{2}{|c|}{ Second } & \multirow{2}{*}{$\begin{array}{c}\text { Grand } \\
\text { Total }\end{array}$} & \multirow{2}{*}{$\begin{array}{c}\text { Process After } \\
\text { Repair }\end{array}$} & \multicolumn{2}{|c|}{ Second } & \multirow{2}{*}{$\begin{array}{c}\text { Grand } \\
\text { Total }\end{array}$} \\
\hline & NVA & VA & & & NVA & VA & \\
\hline $\begin{array}{c}\text { Inner } \\
\text { Diameter } \\
\text { Cutting }\end{array}$ & 184 & 99 & 283 & $\begin{array}{c}\text { Inner \& Outer } \\
\text { Diameter } \\
\text { Cutting }\end{array}$ & 151 & 94 & 245 \\
\hline $\begin{array}{c}\text { Outer } \\
\text { Diameter } \\
\text { Cutting }\end{array}$ & 184 & 113 & 297 & $\begin{array}{l}\text { M.H. Drilling, } \\
\text { Chamfering, \& } \\
\text { Counter Bore }\end{array}$ & 250 & 107 & 357 \\
\hline $\begin{array}{l}\text { Mounting } \\
\text { Hole Drilling }\end{array}$ & 105 & 74 & 179 & $\begin{array}{l}\text { Chamfering } \\
\text { Counter Bore }\end{array}$ & 35 & 13 & 48 \\
\hline $\begin{array}{c}\text { Mounting } \\
\text { Hole } \\
\text { Chamfering }\end{array}$ & 46 & 13 & 59 & Total & 436 & 214 & 650 \\
\hline
\end{tabular}




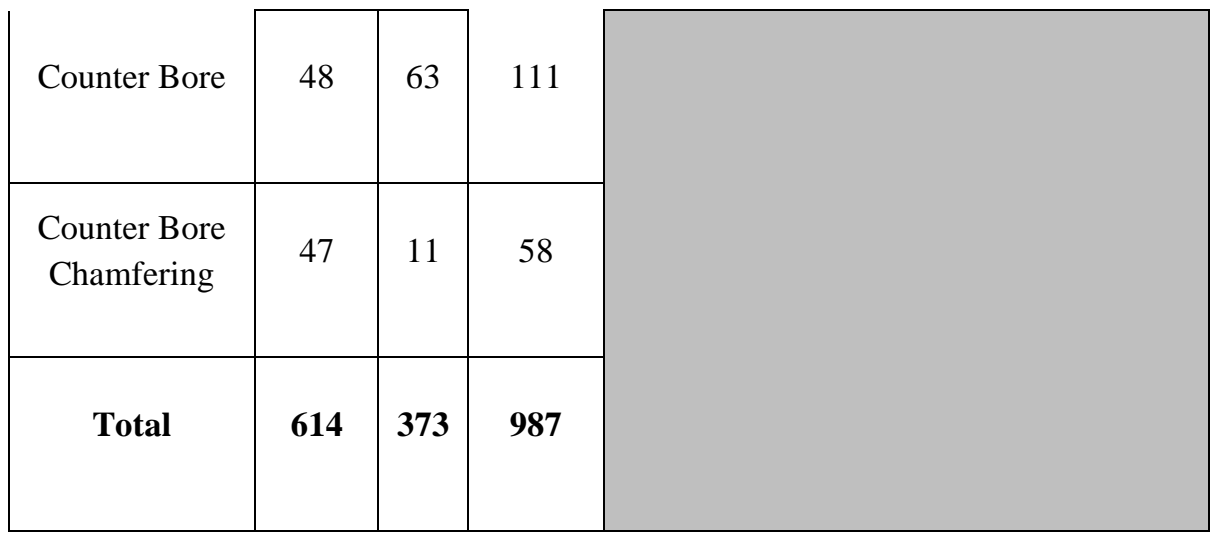

The following is a comparison of capacity efficiency before and after making improvements to the manufacture of disc brake line cutting disks.

Table 5 Comparison of Production Capacity Efficiency

\begin{tabular}{|l|r|r|}
\hline \multicolumn{1}{|c|}{ Improvement } & Sebelum & Sesudah \\
\hline Working time 8 hours (minutes) & \multicolumn{2}{|c|}{480} \\
\hline Cycle Time (second) & 297 & 118 \\
\hline Production Capacity (pcs / hour) & 12 & 31 \\
\hline Actual Production daily (pcs) & 70 & 235 \\
\hline Net working time (hours) & 5,775 & 7,70 \\
\hline Net working time (minutes) & 346,5 & 462,167 \\
\hline Effisiensi kapasitas (\%) & $72 \%$ & $96 \%$ \\
\hline
\end{tabular}

The following is a graph of capacity efficiency comparisons before and after the line cutting disk improvements were made.

\section{CONCLUSION}

\subsection{Conclusion}

Based on observations on waste reduction research on the manufacture of disc brake line cutting disks at the Indonesian Manufacturing Company, the following are some of the conclusions of this study:

1. Based on the results of integrating lean six sigma with the DMAIC, VSM and VALSAT methods, it can be seen that the causes of waste that occur in disc brake manufacturing inline cutting disks are motion, inventory, overproduction, transportation, waiting, and process. The first cause of waste is the motion with the chuck design used which is still separate between the inner and outer cutting processes, so the process uses 2 and 2 manpower, the movement for the Chuck and Soft Jaw set-up is too long, because there are two components for one set up. The second waste is inventory and overproduction, namely the accumulation of material after M.H. Drilling due to the uneven distribution of workloads resulting in inventory accumulation in the chamfering and overproduction processes in the M.H. Drilling. The third waste, namely waiting and inventory in the counterbore process, still uses the manual depth setting method using a micrometer installed on the machine and the inner bosh which must be adjusted to the stopper pin for centering the counterbore process, making the initial setting time too long and processing. unstable.

The fourth waste is transportation and motion with the after material 
International Journal of Engineering Research and Advanced Technology, Vol. 7, No.9, September -2021

through the inner and outer cutting process, the mounting hole drilling will be processed. The location between the inner and outer cutting machines with the mounting hole drilling is still too far away, thus creating a long movement time and requiring additional transportation. The fifth waste is the process, that is, during the chamfering process, sometimes the operator only estimates the size of the part being processed

without any tools or JIG to determine the dimensions according to those specified on the process sheet.

2. The cause of the reduction in the disc brake line cutting disk production cycle time is the total cycle time of the current activity, which is 979 seconds with the bottleneck (longest cycle time) in the outer cutting process, which is 290 seconds. After the repair stage, there was a decrease in the total cycle time to 645 seconds with the longest cycle time after a combination of processes between mounting hole drilling, mounting hole chamfering, and counterbore, namely 354 seconds and divided into three processes with cycle times to 118 seconds and a reduction in the inner and outer processes. outer cutting becomes 246 seconds with two processes using one machine. The reduced cycle time resulted in a capacity efficiency which increased from $72 \%$ to 96\%. This shows that the effect of decreasing cycle time can increase the production capacity of the line cutting disk and increase the resulting output.

3. Based on the analysis of the causes of waste in making disc brake line cutting disks, several recommendations for improvements can be made. First, the process of setting the chuck and soft jaw with improvements made is combining the soft jaw and chuck into one component. From the results of these improvements, there are results for a decrease in cycle time set up from the previous 30 minutes or 1800 seconds to 10 minutes or 600 seconds, a decrease in cycle time set up by 20 minutes or 1200 seconds with a calculation of 30 minutes: 480 minutes $=0.062$ minutes $(3,75$ seconds $/ 4$ seconds). Both the waiting time for the inner and outer cutting processes are still too long, the improvements made are combining the inner and outer cutting processes into one process. By changing the chuck design into one component. Before repairing the datum for the inner cutting process, it was on the outer and vice versa in the outer cutting process, the datum was on the inner. After the design is changed to one component, the datum is in the Weight Reduction Hole material, which previously used two engines and two manpower, after repairs it became one engine and one manpower. The third is the accumulation of work in process (WIP) after the mounting hole drilling process, the improvement of the process between M.H. Drilling, Counter Bore, and Mounting Hole Chamfering are made into one process, using Brother NC machines using hydraulic clamps with wind pressure of 5 bar. There is no need for material handling from one process to another. The counterbore process does not use a manual process with a long set up time. Everything has become a component of the process, only setting tools in the NC program to determine the offset height. With a total cycle time of 357 seconds for three processes with one running. The four taking of each work in process (WIP) are still too far away to be improved, namely from the line cutting disk layout a re-layout was made to U LINE. U-shaped line to make it easier for operators when handling material from each process, so that before repairing from six processes to three processes with only one operator. The five failures during the chamfering counterbore process. Improvements made were adding a stopper to the machine to prevent human errors.

\subsection{Suggestion}

Based on the results of the analysis that has been carried out, the researcher provides suggestions as input and material for consideration as follows:

1. Investments in machines for the cutting disk process increase production capacity with the U LINE layout being made in line with the increasing orders every year from customers with new model parts.

2. Utilization of an internal workshop to make jig cutting in chucks and other tools to reduce the cost of making it externally (subcount).

3. In further research, the latest innovations should be carried out using a CNC robotic system model to reduce the workload on production operators. 
International Journal of Engineering Research and Advanced Technology, Vol. 7, No.9, September -2021

\section{ACKNOWLEDGMENT}

Universitas Mercu Buana Research Centre funded this research. We are grateful for all experts who are willing to be research partners, with no mention of the company name.

\section{REFERENCES}

1. Amin, Syukron, and Muhammad Kholil. (2013). Six Sigma for Business Improvement. Graha Ilmu.

2. Syabrina, R, A, N. (2017). Communication Effectiveness and Efficiency in the 2017 Damar Kurung Gresik Festival.

3. Caesaron, D., \& Simatupang, S. Y. P. S. (2015). Implementation of DMAIC Approach for Improvement of PVC Pipe Production Process (Case Study of PT. Rusli Vinilon). Journal of Metris, 16 (2015): 91-96, 16, 1-6.

4. Fajrian, M. (2018). Application of sifajrianstem value stream mapping to increase the production of spare parts for Mainstand 2SD motorcycles. 10(3), 252-262.

5. Fatma, N. F., \& Pradipta, S. A. (2018). Application of Six Sigma Methodology to Reduce Waste Water Treatment Operational Costs at Pt Clariant Indonesia (Case Study in Chemical Company). 3(2), 59-66.

6. Fernando, Y. C., \& Noya, S. (2014). Production Line OptimizationI With Value Stream Mapping And Value Stream Analysis Tools. Scientific Journal of Industrial Engineering. Volumes 13 (2), 125-133.

7. Firmansyah, A., Yuliana, L., \& Ranata, W. (2020). Analysis of the Implementation of the VSM Method on the Dago Cracker Factory Production System.

8. Fithri, P., \& Sari, R. Y. (2016). Analysis of Measuring Productivity of Alsintan Company CV. Cherry Sarana Agro. Journal of Industrial System Optimization. Volume 14 (1), 138. https://doi.org/10.25077/josi.v14.n1.p138-155.2015

9. Fitriyani, R., Saifudin, S., \& Margareta, K. (2019). Proposed Improvements To Reduce Waste In The Production Process With Lean Manufacturing Methods. PASTI Journal. Vol. XIII (2), 187-201.

10. Ford Motor Company. (2011). Failure Mode and Effects Analysis, FMEA Handbook (with Robustness Linkages). International Journal of Quality \& Reliability Management, $13(5), \quad 286$. https://fsp.portal.covisint.com/documents/106025/14555722/FMEA Handbook v4.2/4c14da5c-0842-4e60-a88b$75 \mathrm{c} 18 \mathrm{e} 143 \mathrm{cf} 7$

11. Ganguly, K. (2012). Improvement Process For Rolling Mill Through The Dmaic Six Sigma Approach. Journal for Quality research. Volumes 6 (3), 221-231.

12. Gautama, P. (2019). Analysis of the Early Stages of Six Sigma Implementation at Tama Kopi and its Implications for Service Quality. InTent Journal. Volumes 2 (1), 85-93.

13. Hamsinah, H. (2018). The Effect of Productivity, Efficiency and Job Satisfaction on Employee Turnover in the Marketing Division of Lempuk Syako Makassar. Innovation, 5(1), 28. https://doi.org/10.32493/inovasi.v5i1.y2018.p28-46

14. Hidayat, R., Tama, I. P., \& Efranto, R. Y. (2006). Application of Lean Manufacturing With VSM And FMEA Methods To Reduce Waste In Plywood Products (Case Study of the Production Dept. of PT Kutai Timber Indonesia). Journal of Universitas Brawijaya. Vol 5 (2), 1032-1043. 
15. Hines, P., \& Rich, N. (1997). The Seven Value Stream Mapping Tools. International Journal of Operations \& Production Management, 17, 46-44.

16. Hospital, I., Medika, A., Lintya, D., \& Karima, S. (2015). Use of Lean Concept to Improve Efficiency of Outpatient Pharmacy Installation Services at Anna Medika Hospital Bekasi. Journal of Hospital Administration. Volumes 2 (1), $29-42$.

17. IGAI Mas Pertiwi, Herlambang, F, S, \& Kristinayanti, W,. (2019). Analysis of Construction Waste Materials on Building Projects in Bandung Regency. Symmetric Journal. vol. 9(1), 185-190.

18 Indexed, S., Venkata, G., Rao, P., Nallusamy, S., \& Narayanan, M. R. (2017). Augmentation Of Production Level Using Different Lean Approaches In Medium Scale Manufacturing Industries. International Journal of Mechanical Engineering and Technology. Volumes 8 (12), 360-372.

19 Kholil, M., \& Mulya, R. (2014). Waste Minimization And Proposed Increasing Efficiency Of Mcb (Mini Circuit Breaker) Production Process With Lean Manufacturing System Approach (At Pt Schneider Electric Indonesia). Systems Research and Applications and Industrial Engineering, 8(1), 44-70.

20 Kurniawan, Y., Luhukay, D., \& Halim, T. (2014). Development of Accounting Information Systems for Production Processes at PT XYZ.ComTech. Volumes 5 (9), 224-235.

21 Lestari, K., \& Susandi, D., (2019). Application of Lean Manufacturing To Identify Waste In The Production Process Of Knitting Fabrics On The Production Floor Of PT . XYZ. Proceedings of the Industrial Research Workshop and National Seminar. Volumes 10 (1), 567-575.

22 Lisano, N., Susanty, A., (2016). Analysis of Waste Waiting in Full Hard Product Manufacturing by Using Process Activity Mapping in Cold Rolling Mill Plants. E-Journal of Industrial Engineering. Volumes 5 (2), 1-7.

23 Muflihin, H. M. H. (2009). Employee Work Productivity Assessment. Journal of Educational Alternative Thinking. Journal of Educational Alternative Thinking. Volumes 14 (2), 1-9.

24 Muhammad, Z. Z. Z., \& Yadrifil, Z. Z. Z. (2018). Implementation of lean manufacturing system to eliminate wastes on the production process of line assembling electronic car components with WRM and VSM method. Proceedings of the International Conference on Industrial Engineering and Operations Management, 2018(JUL), 150-166.

25 Natalia, M,. Partawijaya, W,. Mirani, Z,. (2017). Analysis of Contruction Waste Risk Factors in Construction Projects in Padang City. Civil Engineering Scientific Journal Volume XIV Number 2, October 2017 ISSN: 1858-3695. XIV, 39-45.

26 Pradana, Y. S.P., Handayani, N. U., \& Suliantoro, H. (2017). Analysis of Material Waste in the Production Process of 240ml Aqua Packaging At Pt . Tirta Investama. Volumes 6 (2) 1-9. https://ejournal3.undip.ac.id/index.php/ieoj

27 Profile, S. E. E. (2016). Enhancement of Productivity and Efficiency of CNC Machines in a Small Scale Industry Using Total Productive Maintenance Efficiency Enhancement in CNC Industry using Value Stream Mapping , Work Standardization and Line Balancing. August. https://doi.org/10.4028/www.scientific.net/JERA.25.119

28 Purwanto, A. B., \& Wulandari. O. (2016). The Effect of Motivation, Compensation and Work Environment on Employee Work Productivity. Journal of Business \& Management. Volumes 02 (01), 9-26.

29 Rawabdeh, I. A. (2005). A model for the assessment of waste in job shop environments. International Journal of Operations \& Production Management, 25 No 8.

30 Ristyowati, T., Muhsin, A., \& Conscience, P. P. (2017). Minimization of Waste in Production Process Activities With Lean Manufacturing Concept (Case Study at PT. Sport Glove Indonesia). Options, 10(1), 85. https://doi.org/10.31315/opsi.v10i1.2191

31 Salamah, G., \& Dan, I. (2012). Waste minimization (waste) using a value stream analysis tool to improve production time efficiency (Case study: PT Barata Indonesia). Volumes 1 (1), 1-6.

32 Sasongko, R. N., Sianto, M. E., \& Gunawan, I. (2019). Speaker Assembly Path Simulation To Improve Production Line 
International Journal of Engineering Research and Advanced Technology, Vol. 7, No.9, September -2021

Efficiency. Scientific Journal Widya Teknik. Volumes 18 (1), 1-10.

33 Satria, T., \& Yuliawati, E. (2018). Lean Manufacturing Design Using Waste Assessment Model (WAM) and VALSAT to Minimize Waste (Case Study: PT. XYZ). Volumes 7 (1), 55-63. http://dx.doi.org/10.26593/jrsi.v7i1.2288.55-63

34 Shodiq, M., \& Khannan, A. (2015). Analysis of Lean Manufacturing Applications to Eliminate Waste in the Analysis of Lean Manufacturing Applications to Eliminate Waste in the Production Line of PT Adi Satria Abadi. April, 47-55. https://doi.org/10.26593/jrsi.v4i1.1383.47-54

35 Sudin, A. G. S. A. (2004). The Effect of Manufacturing Strategy on Performance (Study on Medium and Large Manufacturing Industries in Yogyakarta). Manaratha Management Journal. Volumes 3, 1-18

36 Vinilon, P. T. R., Caesaron, D., Simatupang, S. Y. P., Studies, P., Industry, T., \& Technology, F. (2015). Implementation of the DMAIC Approach for Improvement of PVC Pipe Production Processes (Case Studies. 16, 91-96.

37 Yosan, R. B., Kholil, M., \& Purwanto. (2014). Company Productivity Measurement Using Objective Matrix Method. IENACO National Seminar, 215-223.

C. author EMAIL: muhammad_kholil@mercubuana.ac.id 